\title{
Hindi translated version of menopausal rating score questionnaire: a method to evaluate post menopausal symptoms in India
}

\author{
Renuka Malik $^{1 *}$, Chanderkala Pokaria ${ }^{1}$, Swati Singh ${ }^{1}$, Kaveri Khera ${ }^{2}$
}

\begin{abstract}
${ }^{1}$ Department of Obstetrics and Gynecology, PGIMER and Dr. RML Hospital, New Delhi, India
${ }^{2}$ Department of Microbiology, Affinity Biosensors, Goleta, California, USA
\end{abstract}

Received: 16 May 2019

Accepted: 01 July 2019

\section{*Correspondence: \\ Dr. Renuka Malik, \\ E-mail: renucam@yahoo.co.in}

Copyright: () the author(s), publisher and licensee Medip Academy. This is an open-access article distributed under the terms of the Creative Commons Attribution Non-Commercial License, which permits unrestricted non-commercial use, distribution, and reproduction in any medium, provided the original work is properly cited.

\begin{abstract}
Background: There are large number of post menopausal patients in India deserving more care and attention than is given at present.MRS questionnaire in Hindi (MRS-H), a translated and validated version of original MRS Scale (MRS-E), self assessed by patients in their own native language. This tool can be used to assess and document current quality of life as well as improvement with treatment of severe post menopausal symptoms, in Indian population.

Methods: 30 bilingual English and Hindi speaking postmenopausal patients were recruited for this study.MRS Questionnaire has 11 questions covering somatic, pschycological and genitourinary symptoms of menopause. The scoring system is simple. Hindi translation of MRS Questionare was done from English (MRS-E) to Hindi (MRS-H) by 4 independent translations using standard protocol. The MRS-H was tested for internal validity and also compared with MRS - E.

Results: Quality of life is a subjective perception modified by the cultural habitat in which one lives. MRS-H showed high validity and good co-relation with MRS-E. The MRS-H possessed good convergent and discriminant validity. MRS-H showed anICC (Intraclass coefficient) was more than 0.5 and cronbach alpha more than0.5. There was found to be strong correlation between MRS-E and MRS-H questionnaire with all correlation value above 0.7.

Conclusions: The authors recommend the use of the self assessed MRS-H in Hindi should be used to assess menopausal complaints and relief with treatment in India.
\end{abstract}

Keywords: Genitourinary syndrome at menopause, Hot flushes, Menopause, Menopausal score in Hindi, Menopausal rating scale, Post menopausal symptoms, Quality of life at menopause

\section{INTRODUCTION}

Symptom scales for aging women have clinically been used for years and the interest in measuring health-related quality of life (HRQoL) has increased in recent years. ${ }^{1}$ The Menopause Rating Scale (MRS) is a formally validated scale according to the requirements for quality of life instruments. The advantage of using this questionnaire is that it is internationally used and validated in post menopausal women in many countries in native language. It is filled by patient herself and so has the advantage of removing bias and also saving time of health provider. It can also be used to assess and document improvement in quality of life with treatment of severe post menopausal symptoms.

\section{METHODS}

We translated the Menopause Rating Scale English questionnaire (MRS-E) into Hindi (MRS-H) with the 
help of 4 independent health professional and Hindi department of our hospital, using stand forward and backward translation. The Hindi translations were performed using international methodological recommendations for the linguistic and cultural adaptation of HRQoL instruments. 30 postmenopausal, bilingual women, well versed in English and Hindi were recruited for this study from OPD from July to September 2018, of DR RML Hospital, New Delhi, which is a teaching central government Hospital in capital of India. The inclusion criteria for subjects were fluency both verbal and written in English and Hindi language. The MRS questionnaire in English (MRS-E) questionnaire was given to them and score and sub score calculated (Annex1).

They were called again after 2 weeks and the Hindi translated version (MRS-H) given to them (Annex2).

The score and sub score of Hindi version calculated. The scoring scheme is simple, the score increases point by point with increasing severity of subjectively perceived symptoms in each of the 11 items ranging from 0 if no complaints and 4 points for very severe symptoms for both MRS-E and MRS-H. The respondent provides her personal perception by checking one of 5 boxes for each of the items. The composite scores for each of the dimensions (sub-scales) are based on adding up the scores of the items of the respective dimensions. The composite score (total score) is the sum of the dimension scores.

\section{Statistical analysis}

The intraclass correlation coefficient was used to examine the test - retest reliability of MRS-H. The internal consistency of MRS-H was assessed with Cronbach' salpha. Each value of the coefficient that was greater than 0.5 indicated satisfactory agreements. To evaluate criterion validity, the relationship between the individual items and dimension scores of MRS-H was estimated. The floor and ceiling effects of the MRS-H version were assessed by calculating the proportion of subjects who scored minimum and maximum values separately. Pearson's correlation was used to assess correlation between MRS-H and MRS-E. Construct validity was evaluated by comparing the mean scores of MRS-E and MRS-H. Principal Component Analysis with Varimax rotation to divide the items into three factors. The number of factors retained was derived by considering eigen value $(>1)$. All data were analyzed using SPSS for Windows Version 17.0, with a two-tailed $\mathrm{p}$ value of less than 0.05 being considered statistically significant.

\section{RESULTS}

T30 patients attending menopausal OPD of Dr RML Hospital were recruited in study that was well versed in English and Hindi. The average age of our study population was 49 years and the average age at menopause was 47 years. The average education level was graduation and above and the average socioeconomic status of our sample population was upper middle class.

\section{Descriptive statistics of the MRS-E}

The descriptive statistics for each question in MRS -E are listed in Table1. The mean scores for the somatic, psychological and urogenital subscale domains were $6.77,6.73$ and 4.63 respectively. The magnitudes of the standard deviations for each question for the somatic, psychological and urogenital subscale domains were3.63, 5.23 and 3.15 respectively. All correlations between items with its own scale were above 0.4 except for hot flushes, joint discomfort and sexual problems.

Table 1: Scores of the 11 items in the menopause rating scale questionnaire-E in our study population.

\begin{tabular}{|c|c|c|c|c|c|}
\hline MRS -E,QUES & SCORE Mean & SD & Item-total correlation & Floor effect & Ceiling effect \\
\hline 1 & 1.87 & 1.25 & 0.239 & $16.67 \%$ & $10.00 \%$ \\
\hline 2 & 1.13 & 1.28 & 0.508 & $46.67 \%$ & $3.33 \%$ \\
\hline 3 & 1.47 & 1.31 & 0.658 & $30.00 \%$ & $6.67 \%$ \\
\hline 11 & 2.30 & 1.32 & 0.361 & $10.00 \%$ & $26.67 \%$ \\
\hline Somatic (SOM) & 6.77 & 3.63 & 0.537 & $10.00 \%$ & $3.33 \%$ \\
\hline 4 & 1.33 & 1.52 & 0.707 & $46.67 \%$ & $10.00 \%$ \\
\hline 5 & 2.40 & 1.45 & 0.775 & $10.00 \%$ & $3.33 \%$ \\
\hline 6 & 1.27 & 1.55 & 0.679 & $50.00 \%$ & $13.33 \%$ \\
\hline 7 & 1.73 & 1.55 & 0.64 & $33.33 \%$ & $20.00 \%$ \\
\hline Psychological (PSY) & 6.73 & 5.23 & 0.767 & $3.33 \%$ & $3.33 \%$ \\
\hline 8 & 1.93 & 1.34 & 0.282 & $16.67 \%$ & $13.33 \%$ \\
\hline 9 & 1.40 & 1.57 & 0.659 & $43.33 \%$ & $20.00 \%$ \\
\hline 10 & 1.30 & 1.32 & 0.413 & $30.00 \%$ & $13.33 \%$ \\
\hline Genitourinary (GSM) & 4.63 & 3.15 & 0.595 & $3.33 \%$ & $3.33 \%$ \\
\hline
\end{tabular}


Table 2: Characteristics of the 11 items in the menopause rating scale questionnaire-H in our study population.

\begin{tabular}{|llllll|}
\hline MIRS-H QUES & SCORE Mean & S.D & Item-total correlation & Floor effect & Ceiling effect \\
\hline 1 & 1.87 & 1.25 & 0.268 & $16.67 \%$ & $10.00 \%$ \\
\hline 2 & 0.87 & 1.17 & 0.542 & $53.33 \%$ & $3.33 \%$ \\
\hline 3 & 1.67 & 1.49 & 0.561 & $33.33 \%$ & $13.33 \%$ \\
\hline 11 & 2.33 & 1.3 & 0.278 & $6.67 \%$ & $26.67 \%$ \\
\hline Somatic (SOM) subscale & 6.74 & 3.55 & 0.557 & $10.00 \%$ & $3.33 \%$ \\
\hline 4 & 1.4 & 1.61 & 0.746 & $46.67 \%$ & $16.67 \%$ \\
\hline 5 & 1.97 & 1.47 & 0.765 & $20.00 \%$ & $23.33 \%$ \\
\hline 6 & 1.6 & 1.4 & 0.566 & $30.00 \%$ & $10.00 \%$ \\
\hline 7 & 1.83 & 1.56 & 0.624 & $30.00 \%$ & $20.00 \%$ \\
\hline Pscychological (PSY) subscale & 6.8 & 5.11 & 0.755 & $3.33 \%$ & $6.67 \%$ \\
\hline 8 & 1.77 & 1.3 & 0.218 & $16.67 \%$ & $10.00 \%$ \\
\hline 9 & 1.43 & 1.52 & 0.662 & $40.00 \%$ & $16.67 \%$ \\
\hline 10 & 1.37 & 1.35 & 0.416 & $30.00 \%$ & $13.33 \%$ \\
\hline Urogenital (GSM) subscale & 4.57 & 2.99 & 0.607 & $3.33 \%$ & $3.33 \%$ \\
\hline
\end{tabular}

\section{Descriptive statistics and validity of the MRS-H}

The descriptive statistics for each question are listed in Table2.The mean scores for the psychological, somatic and urogenital subscale domains were $6.74,6.8$ and 4.57 respectively. The magnitudes of the standard deviations for each question for the psychological, somatic and urogenital subscale domains were 5.11, 3.55 and 2.99 respectively. All correlations between items with its own scale were above 0.4 except for hot flushes, joint discomfort and sexual problems, as in MRS-E. In addition, substantial floor effects were observed for palpitations $(53.3 \%)$ and depressive mood $(46.67 \%)$.
All correlations between items with its own scale were above 0.4 except for hot flushes, joint discomfort and sexual problems in both MRS-E and MRS-H (Table 1,2).

\section{Comparison between MRS-E AND MRS-H}

The mean score of somatic, psychological and genitourinary symptoms in MRS-E questionnaire are $6.77,6.73$ and 4.63 respectively which is similar to the mean score in MRS-H which is $6.73,6.8$ and 4.57 respectively. The average of the difference in English and Hindi total score was 0.0333 . There was no significant difference between Hindi and English total score with $\mathrm{p}$ value $0.813(>0.05)$ which means both the scores are comparable (Table 3).

Table 3: Comparison between MRS-E and MRS-H.

\begin{tabular}{|llllll|}
\hline & n & Mean \pm SD & Median & Min-Max & Inter quartile range \\
\hline Subscale SOM (English) & 30 & $6.77 \pm 3.63$ & 6.5 & $2-15$ & $4-8$ \\
\hline Subscale SOM (Hindi) & 30 & $6.73 \pm 3.55$ & 6.5 & $2-16$ & $4-8$ \\
\hline Subscale PSY (English) & 30 & $6.73 \pm 5.23$ & 4 & $0-17$ & $3-12$ \\
\hline Subscale PSY (Hindi) & 30 & $6.8 \pm 5.11$ & 5 & $0-16$ & $3-11$ \\
\hline Subscale GSM (English) & 30 & $4.63 \pm 3.15$ & 4 & $0-12$ & $3-6$ \\
\hline Subscale GSM (Hindi) & 30 & $4.57 \pm 2.99$ & 4 & $0-11$ & $3-6$ \\
\hline English total score & 30 & $18.13 \pm 10.61$ & 13.5 & $4-40$ & $10-29$ \\
\hline Hindi total score & 30 & $18.1 \pm 10.34$ & 13.5 & $4-40$ & $11-28$ \\
\hline
\end{tabular}

The average of the difference in English and Hindi total score was 0.0333 . There was no significant difference between Hindi and English total score with $\mathrm{p}$ value $0.813(>0.05)$ which means both the scores are comparable (Figure 1).
The average of the difference in subscales somatic (SOM) English and Hindi Score was 0.03333 with $95 \%$ CI of -0.1743 to 0.2410 . There was no significant difference between Hindi and English subscale somatic score with $\mathrm{p}$ value $0.745(>0.05)$ (Figure 2$)$. 


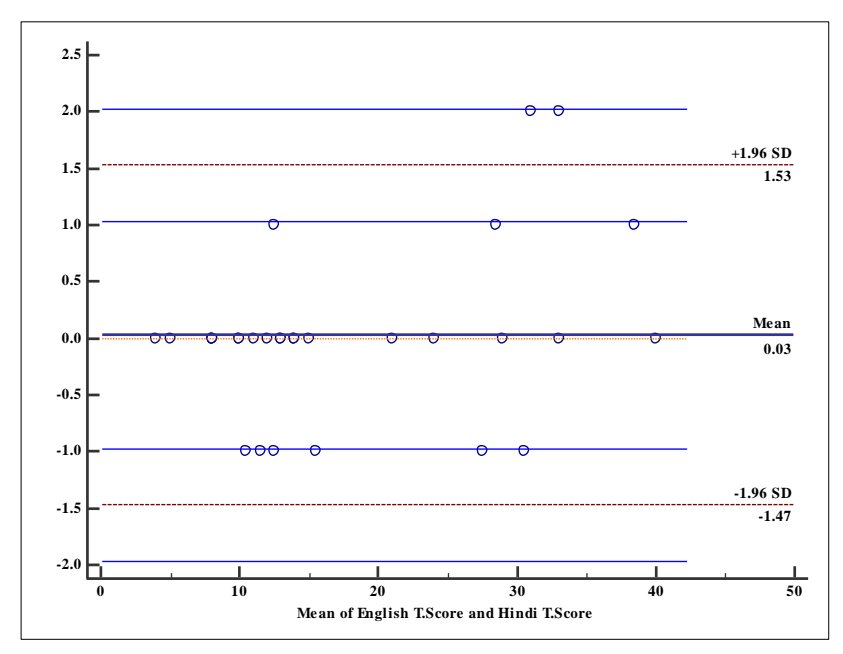

Figure 1: Bland Altman graph comparing total score of MRS-E and MRS-H.

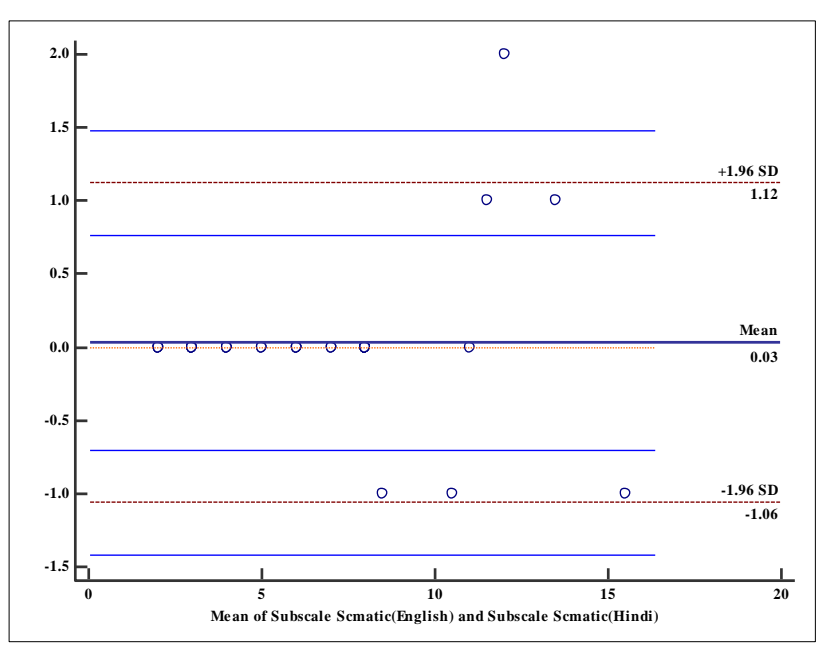

Figure 2: Bland Altman graph comparing SOM subscale of MRS-E and MRS-H.
The average of the difference in Psychological subscale (PSCY) English and Hindi score was -0.06667 with $95 \%$ CI of -0.3055 to 0.1722 .There was no significant difference between MRS-E and MRS-H Psychological subscale(PSCY) score with $p$ value $0.572(>0.05)$ that means both the scores are comparable (Figure 3 ).

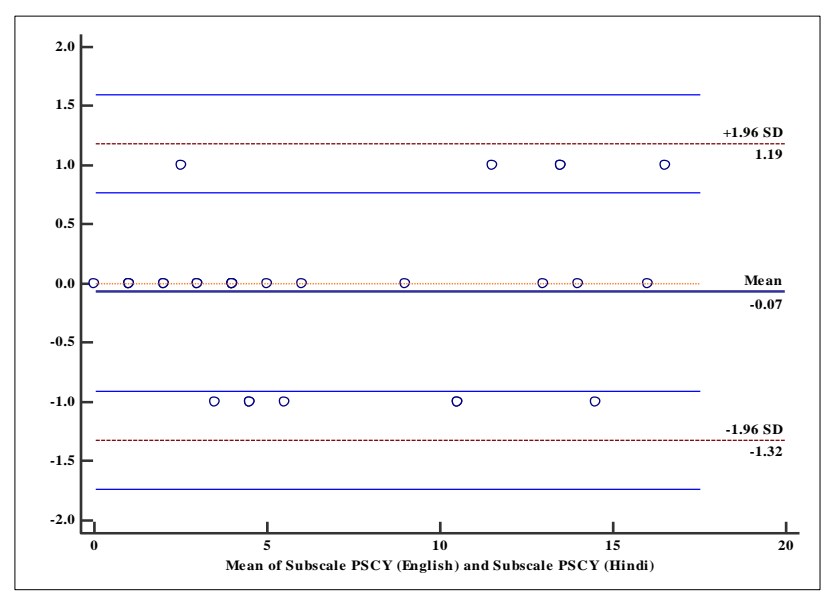

Figure 3: Bland Altman graph comparing (PSCY) subscale MRS-E and MRS-H.

The average of the difference in subscale genitourinary (GSM) English and Hindi score was 0.06667 with 95\% CI of 0.6968 to 0.2030 . There was no significant difference between Hindi and English subscale Genitourinary score with $\mathrm{p}$ value $0.326(>0.05)$ that means both the scores are comparable (Figure 4 ).

The values of Cronbach's $\alpha$ were 0.611 in the somatic (SOM), 0.868 in the psychological (PSY) subscale and 0.519 in the urogenital (GSM) subscale domain, respectively). Test - retest reliability estimated by the ICC (Intraclass coefficient) ranged from 0.519 to 0.866 . In addition, the MRS-H possessed good convergent and discriminant validity (Table 4).

Table 4: Internal consistency, convergent and discriminant validity and test - retest reliability of the M R S-H questionnaire using intraclass correlation coefficient (ICC) and 95\% Confidence interval (CI).

\begin{tabular}{|llllllll|}
\hline Dimension & $\begin{array}{l}\text { Number } \\
\text { of items }\end{array}$ & $\begin{array}{l}\text { Cronbach's } \\
\text { alpha }\end{array}$ & $\begin{array}{l}\text { Range of } \\
\text { inter-item } \\
\text { correlation }\end{array}$ & $\begin{array}{l}\text { Convergent } \\
\text { validity }\end{array}$ & Discriminant & \multicolumn{2}{l}{$\begin{array}{l}\text { Test - retest } \\
\text { reliability }\end{array}$} \\
\hline Somatic & 4 & 0.611 & $0.141-0.483$ & $4 / 4$ & $11 / 12$ & ICC & 95\% CI \\
\hline Psychiatric & 4 & 0.866 & $0.410-0.863$ & $3 / 4$ & $12 / 12$ & 0.611 & $0.320-0.797$ \\
\hline Urogenital & 3 & 0.519 & $0.050-0.473$ & $3 / 3$ & $8 / 9$ & 0.866 & $0.765-0.930$ \\
\hline
\end{tabular}

\section{Construct validity of the MRS-H}

The factor analysis did not group exactly the same as the original instrument (Table 5). The three-factor model was selected and termed as factor 1 with the primary items (i.e. loading_0.4 as a marked influence): items 3 - 7; 910; factor 2 with the primary items 1,2 ; factor 3 with the primary items 8,11 .

Factor 1 corresponded to psychiatric but the difference is that it included some items of somatic and genitourinary 
symptoms. Factor 2 corresponded to somatic symptoms and factor 3 corresponded to genitourinary stmptoms.

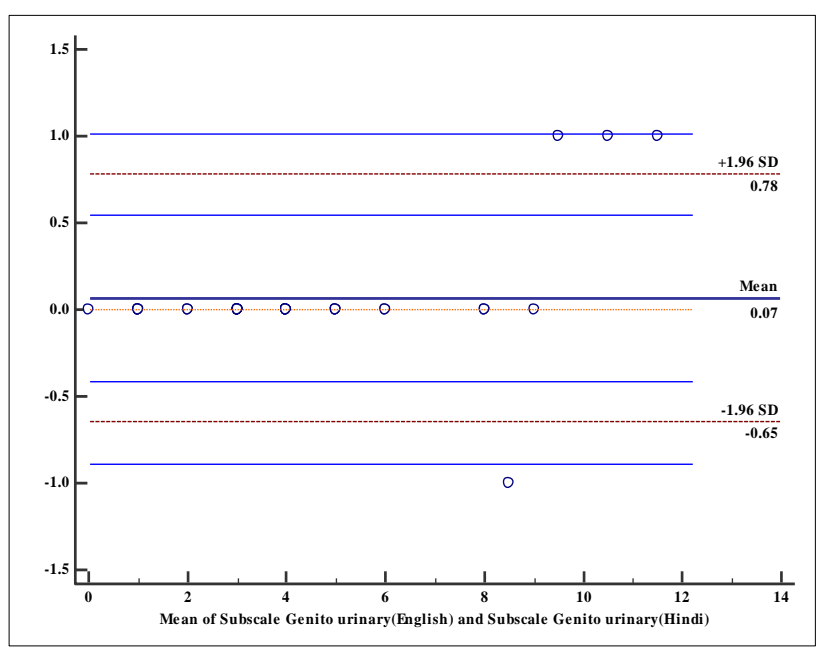

Figure 4: Bland Altman graph comparing GSM in MRS-E and MRS-H.

Table 5: Construct validity from factor analysis of the three-factor model for the menopause rating scale - $\mathbf{H}$.

\begin{tabular}{|c|c|c|c|c|}
\hline \multicolumn{5}{|c|}{ Factor loading } \\
\hline Items & $\begin{array}{l}\text { Factor } \\
1\end{array}$ & $\begin{array}{l}\text { Factor } \\
2\end{array}$ & $\begin{array}{l}\text { Factor } \\
3\end{array}$ & $\begin{array}{l}\text { Variance } \\
\text { explained }\end{array}$ \\
\hline \multicolumn{5}{|c|}{ Factor 1} \\
\hline 3 & 0.806 & 0.064 & -0.051 & $38.11 \%$ \\
\hline 4 & 0.821 & 0.318 & 0.069 & \\
\hline 5 & 0.792 & 0.341 & -0.043 & \\
\hline 6 & 0.781 & 0.101 & -0.145 & \\
\hline 7 & 0.695 & 0.299 & 0.117 & \\
\hline 9 & 0.611 & 0.561 & -0.051 & \\
\hline 10 & 0.637 & -0.002 & 0.349 & \\
\hline \multicolumn{5}{|c|}{ Factor 2} \\
\hline 1 & 0.033 & 0.892 & -0.026 & $18.39 \%$ \\
\hline 2 & 0.369 & 0.718 & 0.282 & \\
\hline \multicolumn{5}{|c|}{ Factor 3} \\
\hline 11 & 0.267 & 0.247 & 0.693 & $11.09 \%$ \\
\hline 8 & 0.401 & 0.126 & -0.701 & \\
\hline
\end{tabular}

\section{Correlation between MRS-E and MRS-H}

There was found to be strong correlation between MRS-E and MRS-H questionnaire with all correlation value above 0.7 (Table 6).

The MRS-H is validated in our study with similar sub score and total scores for postmenopausal symptoms as compared to MRS-E.

\section{DISCUSSION}

In India, about 12.6 million women are above 45 years of age, thus contributing to about $10.4 \%$ of the total population. According to the latest census (2011 census of India), there were about 96 million women aged 45 years and above and this number is expected to increase to 401 million in 2026. ${ }^{1}$ According to the 2017 revision of the World Population Prospects, the Indian population stood at 1,324,171,354. Life expectancy of women in India is 70.1 years (2017 est.). Women in India, on average, could spend approximately 30 year in postmenopausal stage of life. ${ }^{1-3}$ This large number of patients deserves more care and attention than is given at present. Assessing menopausal symptoms as well as response to treatment may be fallacious with serum estradiol as there are wide variations in method of serum estradiol estimation and poor co-relation of severity of menopausal symptoms are seen with serum estadiol levels.4 Using a Questionnaire in Indian menopausal women, which is accepted globally and in patients own language - Hindi, which is the national language of India, can help the gynecologist to understand their symptoms and relief with treatment subsequently.

Table 6: Correlation between MRS -E and MRS -H questionnaire.

\begin{tabular}{|l|l|}
\hline Correlation coefficient between \\
MORS -E and MRS-H
\end{tabular}

Quality of life is a subjective perception modified by the cultural habitat in which one lives. Assessing change in quality of life during menopause is complex, as it involves changes occurring from physiological, psychological, sexual and social domains. According to the World Health Organization (WHO) definition, quality of life is an individual's perception of their status in life, in the context of the culture and value systems in which they live, and in relation to their goals, expectations, standards and concerns. Various tools, around 11, eight specific and three general have been designed to assess health-related quality of life during and after the menopause. $^{5}$ The first widely accepted attempt to measure the severity of menopausal complaints in women was the Kupperman Index. The MRS was developed and validated 20years ago in Germany, in German language by Heinemann to measure HRQoL in post menopausal women. ${ }^{6}$ Over the years, globally this questionnaire has been translated into 10 languages to assess 
postmenopausal symptoms. The first translation was done from the German original scale into English (UK and USA). The English version was used as the source language for the translations into French, Spanish, Swedish, and Mexican/Argentine, Brazilian, Turkish, and Indonesian languages. There are 25 translations of the MRS on its official website and recently translated into Siberian and Chinese language. ${ }^{6-9}$ Other questionnaires like Menopause-Specific QOL questionnaire (MENQOL) are also used with comprise of 36 questions which are more time consuming. ${ }^{10}$ A globally uniform common document like MRS helps in judging post menopausal issues worldwide as well as improvement with treatment. $^{11}$

To the best of our knowledge there is no available translation of this questionnaire in Hindi. Internal consistency, convergent and discriminant validity and test - retest reliability of the $\mathrm{H}$ was high and comparable to MRS-E. The co-relation coefficient was 0.99.0.98 and 0.99 for SOM, PSY and GSM complaints between MRS$\mathrm{E}$ and MRS $-\mathrm{H}$. Test - retest reliability estimated by the ICC (Intraclass coefficient) ranged from 0.519 to 0.866 . It indicated a high concordance among the answers to the MRS at by the same individuals in English and Hindi. In addition, the MRS possessed good convergent and discriminate validity (Table 4). There was found to be strong correlation between MRS-E and MRS-H questionnaire with all correlation value above 0.7 (Table 6 ). The Hindi translated version is validated in our study with similar sub score and total scores for postmenopausal symptoms as compared to the English version, MRS-E.

It is important to use this self administered questionnaire in patients native language, Hindi - our national language to assess the post menopausal symptoms and also the improvement following therapy to remove bias compared to the questionnaire filled by heath care personnel. MRS$\mathrm{H}$ is being used in menopausal OPD in Central government Hospital, Dr RML Hospital and PGIMER, New Delhi, since last one year.

\section{CONCLUSION}

The Hindi version of MRS scale, MRS-H can be widely used in India to study the menopausal symptoms in women and also their response to treatment. The authors recommend its use in menopausal women in India.

\section{ACKNOWLEDGMENTS}

Authors would like to thank Mrs. Seema Dubey, in charge Hindi Section, PGIMER, Delhi for the immense help in translation.
Funding: No funding sources

Conflict of interest: None declared

Ethical approval: The manuscript meets ethical standards. There is no copyright issue with using MRS Questionnaire which is freely downloadable from their website

\section{REFERENCES}

1. Akhtar N. Menopausal symptoms in rural middle aged women: a community based cross sectional study. Int J Reprod Contracept Obstet Gynecol. 2018;7(9):3678-83.

2. Orgi. Census of India Website: Office of the Registrar General and Census Commissioner, India [Internet]. Census of India Website: Office of the Registrar General and Census Commissioner, India. 2019. Available at: http://www.censusindia.gov.in/.

3. Census of India Website: Office of the Registrar General and Census Commissioner, India. Censusindia.gov.in. 2019. Available at: http://www.censusindia.gov.in/.

4. Rosner W, Hankinson SE, Sluss PM, Vesper HW, Wierman ME. Challenges to the measurement of estradiol: an endocrine society position statement. J Clin Endocrinol Metabol. 2013;98(4):1376-87.

5. Jenabi E, Shobeiri F, Hazavehei SM, Roshanaei G. Assessment of questionnaire measuring quality of life in menopausal women: a systematic review. Oman Med J. 2015;30(3):151-6.

6. Heinemann K, Ruebig A. The menopause rating scale (MRS) scale: a methodological review. Health Quality of Life Outcomes. 2004;2:45.

7. Luther AJ, Heinemann, Peter Potthoff. International versions of the Menopause Rating Scale (MRS). Health Quality of Life Outcomes. 2003;1:28.

8. Wu H, Wen S, Hwang J, Huang S. Validation of the traditional Chinese version of the Menopausal Rating Scale with WHOQOL-BREF. Climacteric. 2015;18(5):750-6.

9. Gazibara T, Dotlic J, Kovacevic N. Validation of the Menopause Rating Scale in Serbian language. Arch Gynecol Obstet. 2015;292(6):1379-86.

10. Shobeiri F, Jenabi E, Hazavehei SM, Roshanaei G. Quality of life in postmenopausal women in Iran: a population-based study. J Menopausal Med. 2016;22(1):31-8.

11. Li W, Luo Y, Fu W, Lei R. Acupuncture may improve quality of life in menopausal women: a meta-analysis of randomized controlled trials. Complement Med Res. 2018;25:183-90.

Cite this article as: Malik R, Pokaria C, Singh S, Khera K. Hindi translated version of menopausal rating score questionnaire: a method to evaluate post menopausal symptoms in India. Int J Reprod Contracept Obstet Gynecol 2019;8:3102-9. 
ANNEXURE 1: Menopausal rating scale in English.

Menopause Rating Scale (MRS)

Which of the following symptoms apply to you at this time?

(X ONE Box For EACH Symptom) For Symptoms That Do Not Apply, Please Mark "None").

Symptoms:

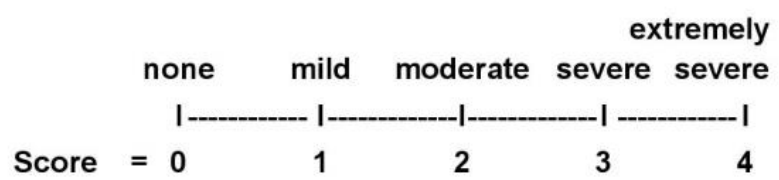

1. Hot flashes, sweating (episodes of sweating)

2. Heart discomfort (unusual awareness of heart beat, heart skipping, heart racing, tightness)

3. Sleep problems (difficulty in falling asleep, difficulty in sleeping through the night, waking up early)

4. Depressive mood (feeling down, sad, on the verge of tears, lack of drive, mood swings).

5. Irritability (feeling nervous, inner tension, feeling aggressive)

6. Anxiety (inner restlessness, feeling panicky)

7. Physical and mental exhaustion (general decrease in performance, impaired memory, decrease in concentration, forgetfulness).

8. Sexual problems (change in sexual desire, in sexual activity and satisfaction)

9. Bladder problems (difficulty in urinating, increased need to urinate, bladder incontinence)

10. Dryness of vagina (sensation of dryness or burning in the vagina, difficulty with sexual intercourse)

11. Joint and muscular discomfort (pain in the joints, rheumatoid complaints) 
ANNEXURE 2: The Hindi Translated version of menopausal rating scale, MRS-H.

\section{रजोनिवृति आकलन तालिका (एमआरएस)MRS-H}

आप पर इस समय कौन से लक्षण लागू होते हैं? प्रत्येक लक्षण के लिए कृपया उचित कॉलम में सही का निशान $(\sqrt{ })$ लगाएँ । जो लक्षण लागू न हों उनके लिए 'कोई'नहीं' कॉलम पर ( $)$ निशान लगाएँ।

लक्षणः

अंक
हल्का

1
मध्यम

2

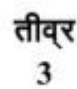

अत्यन्त तीव्र 4

1. तेज गर्मी लगना/पसीना आना (बार बार पसीना आना )

2. दिल की धड़कन संबंधी शिकायतें (असामान्य रूप से दिल धड़कना, रूक रूक कर दिल धड़कना, तेजी से दिल धड़कना, दिल में जकड़न सी महसूस होना)

3. नींद संबंधी शिकायतें (नींद न आना, आराम से नींद न आना, नींद जल्दी खुल जाना)

4. उदासी (बहुत उदास, दुखी सा महसूस होना कि आँसू ही निकलने वाले हों, कोई काम करने की इच्छा न होना, जल्दी गुस्सा आ जाना)

5. चिड़चिड़ापन (घबरा जाना, मानसिक तनाव, गुस्सा आना)

6. चिन्ताग्रस्त (बेचैनी महसूस होना, चिन्तित होना)

7. शारीरिक एवं मानसिक थकान (रोजमर्रा के काम करने में परेशानी महसूस होना, याद्दाश्त कम हो जाना, एकाग्रता में कमी, जल्दी भूल जाने की समस्या होना)

8. सैक्स संबंधी परेशानियाँ (सैक्स के प्रति इच्छा में बदलाव, सैक्स क्रिया और संतुष्टि में परिवर्तन)

9. मूत्राशय संबंधी समस्या (पेशाब करने में दिक्कत होना, बार-बार पेशाब आना, पेशाब निकल जाना)

10. योनि में शुष्कता (योनि में सूखापन, जलन महसूस होना, सहवास में परेशानी महसूस होना)

11. जोड़ों एवं मांसपेशियों की परेशानी (जोड़ो में दर्द, गठिया की शिकायत)

Translated by seema dubey,renuka malik,chanderkala,kaveri khera 